\title{
Correction: Medication Reconciliation in Patients Hospitalized in a Cardiology Unit
}

\section{The PLOS ONE Staff}

The second author's name is spelled incorrectly. The correct name is: Gláucia Noblat de Carvalho Santos.

Additionally, the fourth author's name is spelled incorrectly in the citation.

The complete, correct citation is:

Magalhães GF, Santos GNC, Rosa MB, Noblat LACB (2014) Medication Reconciliation in Patients Hospitalized in a Cardiology Unit. PLoS ONE 9(12): e115491. doi:10.1371/journal. pone. 0115491

\section{Reference}

1. Magalhães GF, Santos GBNdC, Rosa MB, Noblat LdACB (2014) Medication Reconciliation in Patients Hospitalized in a Cardiology Unit. PLoS ONE 9(12): e115491. doi: 10.1371/journal.pone.0115491 PMID: 25531902

\section{G openaccess}

Citation: The PLOS ONE Staff (2015) Correction: Medication Reconciliation in Patients Hospitalized in a Cardiology Unit. PLOS ONE 10(3): e0123362. doi:10.1371/journal.pone.0123362

Published: March 31, 2015

Copyright: @ 2015 The PLOS ONE Staff. This is an open access article distributed under the terms of the Creative Commons Attribution License, which permits unrestricted use, distribution, and reproduction in any medium, provided the original author and source are credited. 